\title{
Histological Changes of Oxytocin on Postpartum Uterus in Cows
}

\author{
S. Alagar*, M. Selvaraju and R. Ezakial Napolean \\ Department of Veterinary Gynaecology and Obstetrics, Veterinary College and Research \\ institute, Namakkal - 2, Tamil Nadu, India \\ *Corresponding author
}

\begin{tabular}{|c|c|}
\hline & A B S T R A C T \\
\hline $\begin{array}{l}\text { K e y w o r d s } \\
\text { Crossbred cows, } \\
\text { Endometrial tissue, } \\
\text { Histology, Oxytocin } \\
\text { and Postpartum }\end{array}$ & \multirow{3}{*}{$\begin{array}{l}\text { The puerperal uterine soundness is essential for the re-establishment of postpartum ovarian } \\
\text { cyclicity and next pregnancy. Normally calved } 18 \text { healthy Holstein Friesian crossbred } \\
\text { cows aged between } 2^{\text {nd }} \text { and } 5^{\text {th }} \text { lactations were selected immediately after parturition. Day } \\
\text { of parturition was considered as day } 0 \text { of the experiment. All the selected cows were } \\
\text { randomly and equally divided into } 2 \text { experimental groups viz., group I (Treatment) and II } \\
\text { (control). The endometrial tissue collected on day } 10 \text { and } 30 \text { postpartum in two groups } \\
\text { through Albuchins's biopsy catheter. In group I on day } 10 \text { postpartum, histologically the } \\
\text { endometrium showed involution process, with mild neutrophilic and mononuclear } \\
\text { infiltration. When compared to day } 10 \text { postpartum, the regenerative changes of epithelium } \\
\text { and endometrial glandular activities were predominant on day } 30 \text { postpartum in group I } \\
\text { cows than group II. }\end{array}$} \\
\hline Article Info & \\
\hline $\begin{array}{l}\text { Accepted: } \\
\text { 07 February } 2018 \\
\text { Available Online: } \\
10 \text { March } 2018\end{array}$ & \\
\hline
\end{tabular}

\section{Introduction}

Reproductive performance of dairy cows after the voluntary waiting period is highly related to the health status of the uterus after calving (Dijkhuizen and Stelwagen, 1985; Ferguson and Galligan, 2000). The complete uterine involution range is 26 to 52 days after calving, but the changes after 20 to 25 days after calving are generally almost imperceptible.

Pathak and Bansal (2012) observed that the endometrial glands were simple or branched tubular glands of which few were coiled distally. They were lined with simple columnar epithelium. These glands were more active during the follicular phase as compared to the luteal phase of the oestrous cycle. But the secretary activity was more pronounced during the luteal phase in cows.Oxytocin injection in the postpartum period did not improve production and reproduction traits in buffaloes and cows (Mustafa et al., 2008 and Palomares et al., 2010), whereas according to Qureshi and Ahmad (2008) the uterine involution was complete after an appropriate period of time after oxytocin treatment.

Intravenous injection of oxytocin (5 IU) resulted in a strong increase in uterine contractility on day 2 postpartum, however, the amplitude and duration of the response decreased by day 4 postpartum in cows (Kundig et al., 1990). At days 10, 20 or 30 
postpartum, intravascular treatments with 30 , 150 and 300 IU oxytocin evoked markedly elevated plasma levels of 15-ketodihydroprostaglandin $\mathrm{F}_{2} \alpha \quad\left(\mathrm{PGF}_{2} \alpha\right.$ metabolite), although the magnitude of the response decreased with advancing puerperium (Del Vecchio et al., 1990).

\section{Materials and Methods}

Normally calved 18 healthy Holstein Friesian crossbred cows aged between $2^{\text {nd }}$ and $5^{\text {th }}$ lactations were selected immediately after parturition. Day of parturition was considered as day 0 of the experiment. All the selected cows were randomly and equally divided into 2 experimental groups viz., group I and II (control). Therefore each group consisted of 9 cows. On day 2 postpartum, cows of group I and II were treated with an intramuscular injection of 50 IU oxytocin $(10 \mathrm{ml}$, Syntophar ${ }^{\circledR}$, Interphar Healthcare Pvt. Ltd., Chandigarh, India) and $5 \mathrm{ml}$ normal saline (Parental drugs (India) limited, Indore, Madhya Pradesh, India), respectively.

\section{Endometrialbiopsy}

The ideal endometrial tissue for interpretation was found to be at least $10-20 \mathrm{~mm} \times 3 \mathrm{~mm}$ in both epithelial cell layer and the glandular architecture (Raja et al., 2012). Albuchin's uterine biopsy catheter (Plate. 1) was used to obtain endometrial biopsy samples as per the technique followed by Palanisamy (2012) with slight modifications. Endometrial biopsy was taken from the all experimental and control cows on (i) day10 and (ii) day 30postpartum.

\section{Results and Discussion}

Histology of endometrium in the control cows on day 10 postpartum showed mild mononuclear infiltration and congestion in the endometrium along with few neutrophils. But, on day 30 postpartum, 2 cows in control group showed endometrial glandular proliferation with few neutrophils. In experimental cows (group I), on day 10 postpartum, the endometrium showed involution process, with mild neutrophilic and mononuclear infiltration. The mucin secretion was also noticed. The increased endometrial glandular activity was seen. Focal mild mononuclear infiltration and mild fibrosis were seen in few cases. Squamous metaplasia of uterine epithelium was noticed in one cow. These regenerative changes of endometrium on day 10 postpartum were prominent in group I (oxytocin) than control group. These proliferative changes were minimal in control group.

On day 30 postpartum, many uterine ecbolics treated cows had increased glandular activity with extensive lymphocytic infiltration and increased vascular spaces. The glandular secretion was predominant in few cases. Moderate neutrophilic and mononuclear infiltration was noticed. Few cows showed the presence of fibrous tissue.

Plate.1 Albuchin's uterine biopsy catheter-with open tissue grasper

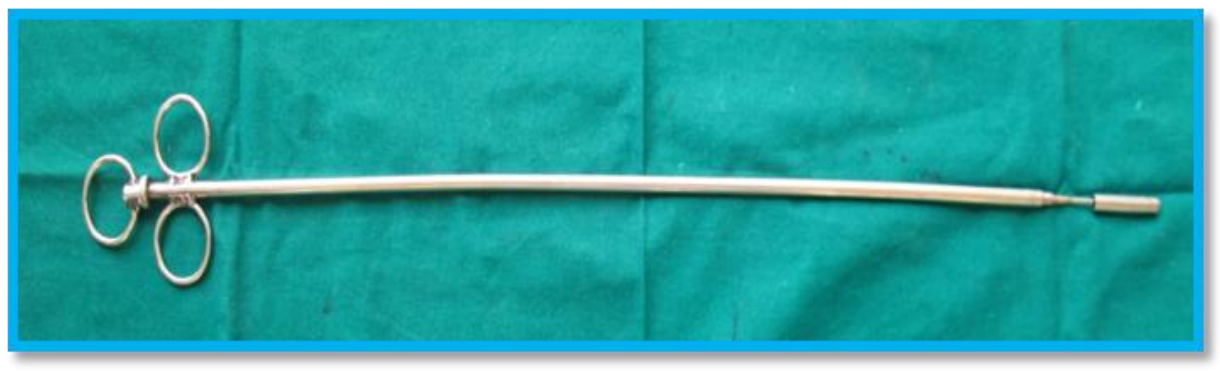


Fig.1 Histology of endometrium in postpartum cows treated with uterine ecbolic

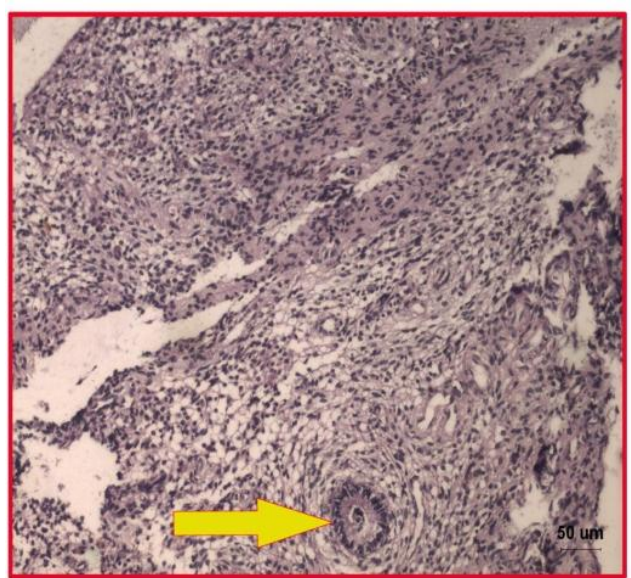

Day-10

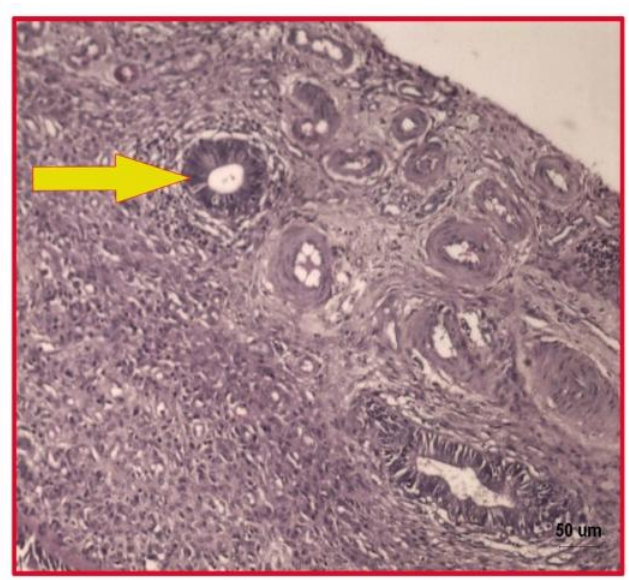

Day-30

Fig.1 Group-I indicates endometrial gland and its secretory activity

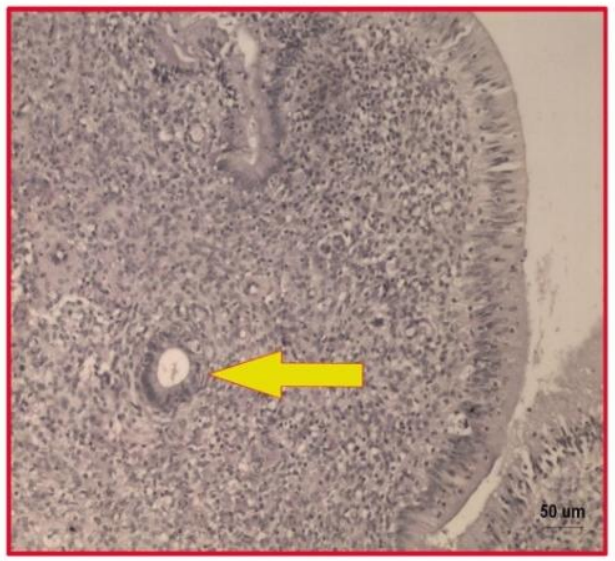

Day-10

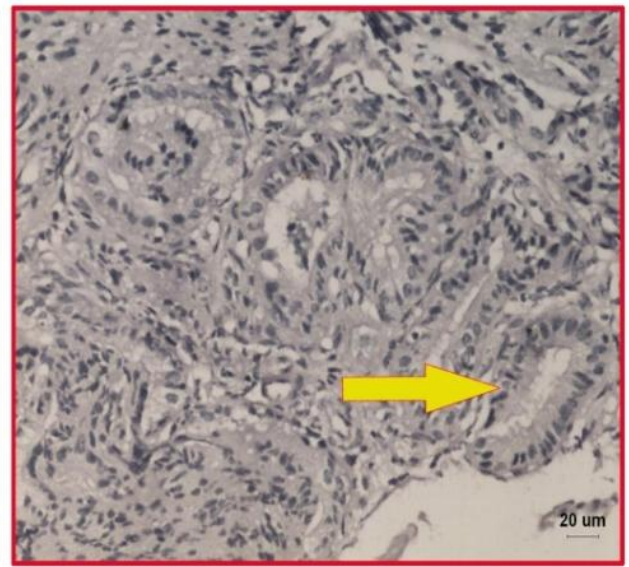

Day-30

Fig.2 Group-II indicates endometrial gland and its secretory activity

When compared to day 10 postpartum, the regenerative changes of epithelium and endometrial glandular activities were predominant on day 30 postpartum in experimental groups especially in group I cows (Fig. 1). These regenerative changes were very minimal in group II (control) (Fig. 2) on day 30 postpartum.

In this study, on day 10 , postpartum uterine lining epithelium was found to be normal with pseudostratified columnar type. Endometrium showed involution process with mild neutrophilic and mononuclear infiltration. The endometrial glandular activity was seen in few cases with increased vascular spaces. On day 30 postpartum there was an increased endometrial glandular activity with extensive lymphocytic infiltration. These observations were in accordance with the findings of Prasad and Krishna (2009) in postpartum normally calved cows. These endometrial involution and regenerative changes clearly reflected on the conception rate in each treatment and control groups.

\section{References}

Bonnett, B.N., S.W. Martin and A.H. Mekk, 1993. Associations of clinical findings, bacteriological and histological results of endometrial biopsy with reproductive 
performance of postpartum dairy cow. Prev. Vet. Med., 15: 205-220.

Del Vecchio, R.P., C.C. Chase, P. Bastidas and R.D. Randel, 1990. Oxytocin-induced changes in plasma 13, 14 dihydro-15-keto prostaglandin $\mathrm{F}_{2} \alpha$ concentrations on days 10 30 postpartum in the bovine. J. Anim. Sci., 68: 4261-4266.

Dijkhuizen, A.A. and J.R. Stelwagen, 1985.Economic aspects of reproductive failure in dairy cattle. Financial loss at the farm level. Prev. Vet. Med., 3: 251-263.

Ferguson, J.D. and D.T. Galligan, 2000.Assessment of reproductive efficiency in dairy herds.Com. Cont. Edu. Prac. Vet., 22: 150-158.

Gilbert, R.O., S.T. Shin, C.L. Guard, H.N. Erb and M. Frajblat, 2005.Prevalence of endometritis and its effects on reproductive performance of dairy cows. Theriogenology, 64: 1879-1888.

Kundig, H., R. Thun and K. Zerobin, 1990.Uterine motility in the cow during late pregnancy, parturition and puerperium. II. Drug Influence. Schweiz Arch Tierheilk, 132: 515-524.

Mustafa, M.Y., K. Saleem, R. Munir and T.M. Butt, 2008.Effect of oxytocin on the productive and reproductive performance of buffalo and cattle in Sheikhupura-Pakistan (a field study). Livest. Res. Rural Dev., 20: No. 193.

Palanisamy, 2012.Efficacy of immunomodulators, lugol's iodine and prostaglandin $\mathrm{F}_{2} \alpha$ in the treatment of post-partum endometritis in cows. Ph.D., thesis submitted to Tamil Nadu Veterinary and Animal Sciences University, Chennai, Tamil Nadu.

Palomares, R.A., J.C. Gutiérrez, G. Portillo, J.C. Boscan, M. Montero, Y. López, H.S. Maxwell, R.L. Carson and E. Soto, 2010. Oxytocin treatment immediately after calving does not reduce the incidence of retained fetal membranes or improve reproductive performance in crossbred Zebu cows. Theriogenology, 74: 1414-19.

Pathak, D. and N. Bansal, 2012.Histomorphology of the endometrial gland of buffalo. Indian Vet. J., 89: 25-28.

Prasad, B.C. and K.M. Krishna, 2009.Effect of RFM on histomorphology of uterine endometrium in cross bred cows. Tamilnadu J. Vet. Anim. Sci., 5: 164-166.

Qureshi, S.M. and N. Ahmad, 2008.Interaction of calf suckling use of oxytocin and milk yield with reproductive performance of dairy buffaloes. Anim. Reprod. Sci., 106: 380-392.

Raja, S., T.G. Devanathan, K. Kulasekar, N. Pazhanivel and C. Balachandran, 2012.Comparison of white side test and endometrial biopsy for diagnosis of endometritis in repeat breeding cows. Indian $J$. Anim. Reprod., 48: 582-586.

Schalm, O.W., N.C. Jain and E.J. Corrol, 1975.Veterinary haematology. $3^{\text {rd }}$ edition, Lea and Febiger, Philadelphia, USA.

Singh, J., S.P.S. Ghuman, D. Dadarwal, M. Honparkhe, G.S. Dhaliwal and A.K. Jain, 2010. Estimations of blood plasma metabolites following melatonin implants treatment for initiation of ovarian cyclicity in true anestrus buffalo heifers. Indian J. Anim. Sci., 80: 229231.

Singh, J., S.S. Sidhu, G.S. Dhaliwal, G.R. Pangaonkar, A.S. Nanda and A.S. Grewal, 2000. Effectiveness of lipopolysaccharide as an intrauterine crossbred cows. Anim. Reprod. Sci., 59: 159-66.

Uthai, T.S., Q. Chen, S.E. Kirton, M.A. Fenwick, Z. Cheng, J. Patton, A.A. Fouladi-Nashta and D.C. Wathes, 2013. Influence of energy balance on the antimicrobial peptides S100A8 and S100A9 in the endometrium of the postpartum dairy cow. Reprod., 145: 527-539.

Vandeplassche, M. and R. Bouters, 1983. Phagocytosis in the blood and uterine exudates of mares cows and sows. World Assn. Vet. Lab. Dia. Ames, 1: 83-89.

\section{How to cite this article:}

Alagar, S., M. Selvaraju and Ezakial Napolean, R. 2018. Histological Changes of Oxytocin on Postpartum Uterus in Cows. Int.J.Curr.Microbiol.App.Sci. 7(03): 448-451. doi: https://doi.org/10.20546/ijcmas.2018.703.053 